\title{
Integrated Elements of Early Warning Systems to Enhance Disaster Resilience in the Arab Region
}

\author{
Al Hmoudi, Abdulla, Mohamed El Raey ${ }^{1}$ and Aziz Zeesha ${ }^{2}$ \\ 1. Salford University, $U K$ \\ 2. Center of Remote Sensing and Risk Reduction, Institute of Graduate Studies and Research, University of Alexandria, Alexandria
}

\begin{abstract}
The Arab region's coastal zones are of immense importance. Almost all Arab countries need to build up resilience for vulnerable communities and carry out proactive planning for integrated coastal zone management and development of early warning systems for vulnerable coastal areas. It is clear that through the analysis of past natural disasters, the links between the four elements (risk knowledge, monitoring and warning service, dissemination and communication, response capability) of EWS (early warning systems) are weak, leading to a reduced effectiveness of the system. The focus is on the development of technology more than on members of the community at risk. There is also weakness in institutional cooperation and one of the main challenges is in early warning. This problem has encouraged the researcher to propose a guideline for early warning of natural disasters and increase its effectiveness by involving members of the community and improving institutional cooperation between stakeholders. The objective of this paper is to identify and assess some of the main areas vulnerable to sea level rise in the Arab world. A survey of case studies in the UAE (United Arab Emirates) and Egypt is undertaken. The main objectives are to identify vulnerabilities from coastal flooding, assess adaptation measures and point out the urgent need to build up institutional and human capacities in response to the problem, identify gaps, points of strength and points of weakness in early warning systems and discuss options for adaptation and the need for implementing major elements of the EWS.
\end{abstract}

Key words: Early warning, natural disasters, community, vulnerable, coastal zones.

\section{Introduction}

The Arab region consists of 22 countries who are all members of the LAS (League of Arab States), 10 in Africa and 12 in West Asia. It enjoys extended coastal zones on the Mediterranean Sea, the Red Sea, the Arabian Gulf and the Atlantic Ocean where large percentages of population live in a number of highly populated cities along the coast. In addition, the growth of population and the tourism in coastal areas has been well observed [1]. Fig. 1 gives an overall view of the size of population at risk of impacts of climate change in the area.

According to recent results of the World Bank studies, individual Arab countries will be affected differently under various sea level rise scenarios.

Corresponding author: Abdulla Ali Ahmed Mohamed Alsagheiry Al Hamoudi, Ph.D., researcher, research field: natural disaster management. E-mail: ab18205@ hotmail.com.
Qatar, the UAE (United Arab Emirates), Kuwait, and Tunisia are most vulnerable in terms of their land mass. One to three percent of land in these countries will be affected by a $1 \mathrm{~m}$ SLR. Moreover, the Egypt's economy is the most vulnerable by far, for SLR of 1 $\mathrm{m}$, more than $6 \%$ of its GDP is at risk, which rises to more than $12 \%$ for an SLR of $3 \mathrm{~m}$.

The UAE faces various socio-technical challenges. Firstly, the role of communities within EWS (early warning systems) is not clearly defined. Also, the members of communities are uninformed and unaware of federal plans, and as results do not know the procedures to be carried out on receipt of early warning signals. Dhanhani [2] has highlighted how a lack of an end-to-end and people centered approach on EWS results in low levels of preparedness and a general lack of knowledge regarding emergency management plans. Secondly, the UAE has a huge 
expatriate population who does not speak Arabic. The presence of other languages such as English, Persian,

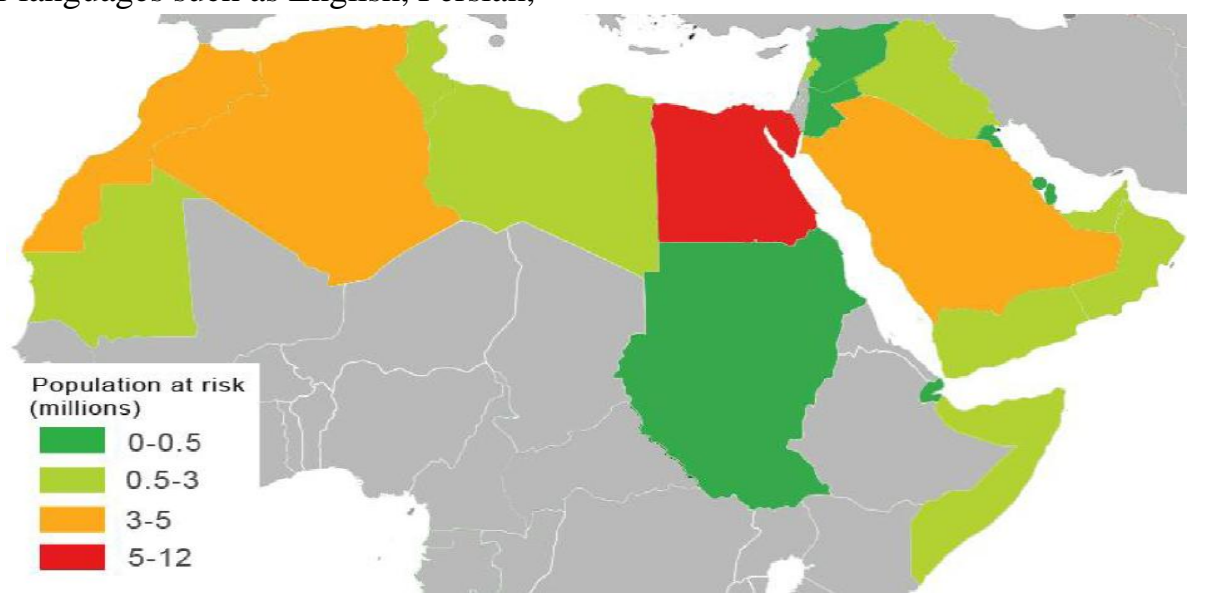

Fig. 1 Arab world indicating population at risk from change in colors (Afed, 2009).

Hindi, and Urdu create significant communication challenges.

As identified by $\mathrm{Al}$ Ameri, there are significant weaknesses in the transfer of understandable warning messages and preparedness information to those at risk and there is no networking and communication among all stakeholders.

On the other hand, Egypt has suffered from a limited ability for natural disaster prevention, and its response capacity has been constrained by a highly centralized decision-making structure. The Egyptian city, Alexandria, is vulnerable to impact of sea level rise, extreme events and tsunami. Several areas are below mean sea level especially in the south eastern side of the city and no early warning system is available to the coastal population. However, several Middle Eastern and Arab countries including the UAE and Egypt have witnessed a rise over the past five years in extreme events including the recent severe cyclone storm [3].

\section{Methodology}

In this paper, the author will discuss the two case studies. Firstly, a case study in the UAE is the Phet storm in the town of Sharm and another is in Egypt namely the Alexandria storm. The best research approach for this study is the case study as it is identified as the most suitable approach for this research for a variety of justifiable reasons. Yin [4] defined the case study method as an empirical inquiry that is conducted to investigate a contemporary phenomenon within its real life context. A case study explores a research topic or phenomenon within its context, or within a number of real-life contexts [5]. Yin [6] also highlights the importance of context, adding that, within a case study, the boundaries between the phenomenon being studied and the context within which it is being studied are not always apparent. It may use quantitative or qualitative methods and many case study designs use a mix of these methods to collect and analyze data [6]. The case study approach provides the opportunity to ask penetrating questions and capture the richness of organizational behaviour. Creswell [7] argues that case study research involves the study of an issue explored through one or more cases within a bounded system such as a setting and a context. Yin [6] also points out that case studies provide the opportunity of dealing with a full variety of evidence such as documents, archival records, interviews, direct observations and physical artefacts. The case study approach falls within the idealism stance in terms of ontological undertakings, subjective measures paradigm in terms of the epistemological undertakings 
and value-laden stance in terms of axiological undertakings. In the first case study, the decision-makers in federal plan of disaster management in the UAE were interviewed. From this plan, researchers selected the five Ministries which are related to the study, the interviews lasted for about 40 to 60 minutes. In the second case study, in Egypt, the researcher investigated the storm on the coastal city of Alexandria; then a questionnaire was prepared and administered by personal interviewers using a random sample of 100 persons representing fishermen, industry workers, businessmen, farmers and others who were some of the main stakeholders in the Alexandria Governorate. Although this sample is not statistically significant, it is sufficiently considered to provide broad indications of major directions. A supplement to the questionnaire was supplied and used to explain the problem in order to upgrade awareness among vulnerable groups.

\section{A Case Study in the UAE}

In 2010 strong south-easterly winds brought the Phet storms. Lightning and heavy rain caused flooding in the town of Sharm. The relief operation, conducted by the Fujairah Civil Defence and Fujairah Police, was broadly effective. However, there was a lack of EWS and appropriate logistic support, reflecting the need for a better monitoring and warning service, and better dissemination and communication as a part of the early warning system.

\subsection{Location}

Sharm is a town located in the northern part of the Emirate of Fujairah. It is located at $25^{\circ} 287 \mathrm{~N}-56^{\circ} 21$ $37 \mathrm{E}$, about $20 \mathrm{~km}$ from Dibba and $50 \mathrm{~km}$ from Fujairah City. Sharm overlooks the Indian Ocean coast (Fig. 2) and lies on the eastern part of the Arabian Peninsula. The population is approximately 2,500 and the total number of houses about 120 [8].

\subsection{Description of the Disaster}

The UAE Ministry of Interior closed the Fujairah Corniche to avoid any risks to visitors that may have arisen from the hurricane. Witnesses in Sharm reported that rainwater flooded the Corniche Park and surrounding areas. Looking at water concentrations in several areas, they were concerned that losses would occur similar to those left by the passage of Cyclone Gonu in the region in June 2007. The Director General of Civil Defense oversaw coordination between the municipality, the police and Red Crescent Societies. The Abu Dhabi Police rescue unit was stationed in Fujairah for three days in case of any emergency. The Director General said the water reached the streets of 


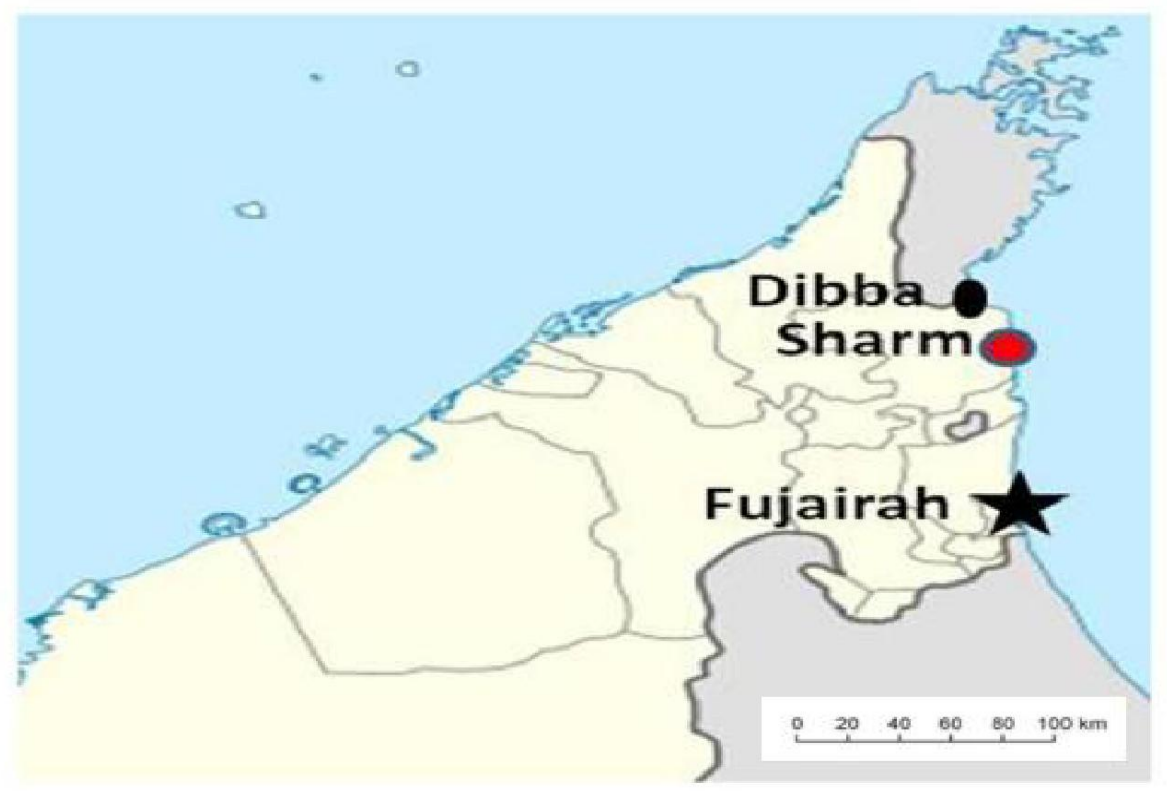

Fig. 2 Location of Sharm (Dhanhani, 2010).

Sharm area and damaged the municipality. He added that the competent authorities took all measures to restore normality, reassuring parents that they will not face problems with transportation and schools. The National Centre for Meteorology and Seismology predicted high waves on the east coast of the state inundating low lying areas the nearby streets of Sharm Beach (Fig. 3).The Phet storm created serious problems as people lost their land, their crops, their boats, and their basic livelihoods. Around 30 houses, two mosques and ten farms, and more than ten cars were damaged. Roads to Dibba and KhorFakkan were cut off. Many cars and houses in Sharm and the major roads from the Dibba and Fujairah were under more than $1 \mathrm{~m}$ of water, forcing hundreds of motorists to abandon their vehicles and seek safety on higher ground. Debris and mud were deposited in streets and all people were evacuated from their houses which suffered considerable damage. The flood affected more than 50 families in different parts of Sharm town. It washed away tens of hectares of land and damaged property worth more than 10 million dollars. Because of the low gradient in the lower region, inundation was widespread and long-lasting in Sharm, flood waters disrupted roads and services in the town (Fig. 3).

Pictures $(\mathrm{C}, \mathrm{D})$ show a car stuck in the flood caused by the storm and the latest picture shows some of the children who are using boats in their homes.

\subsection{Analyzing Field Survey Results in Sample Study}

The interviews have been conducted with the decision-makers at the authorities involved in natural disaster management in the UAE and those in charge of the establishments involved in disaster management, to illustrate how comprehensive and integrated the elements of early warning systems to enhance disaster resilience are in the UAE. The interviews focused on the four elements of early warning, knowledge of the risks, monitoring and dissemination of information and communications and response (Table 1).

- The coordination and integration process in the field of natural disasters management and the risks caused in the Emirate of Fujairah is incomplete; reaching only $60 \%$ at best. 

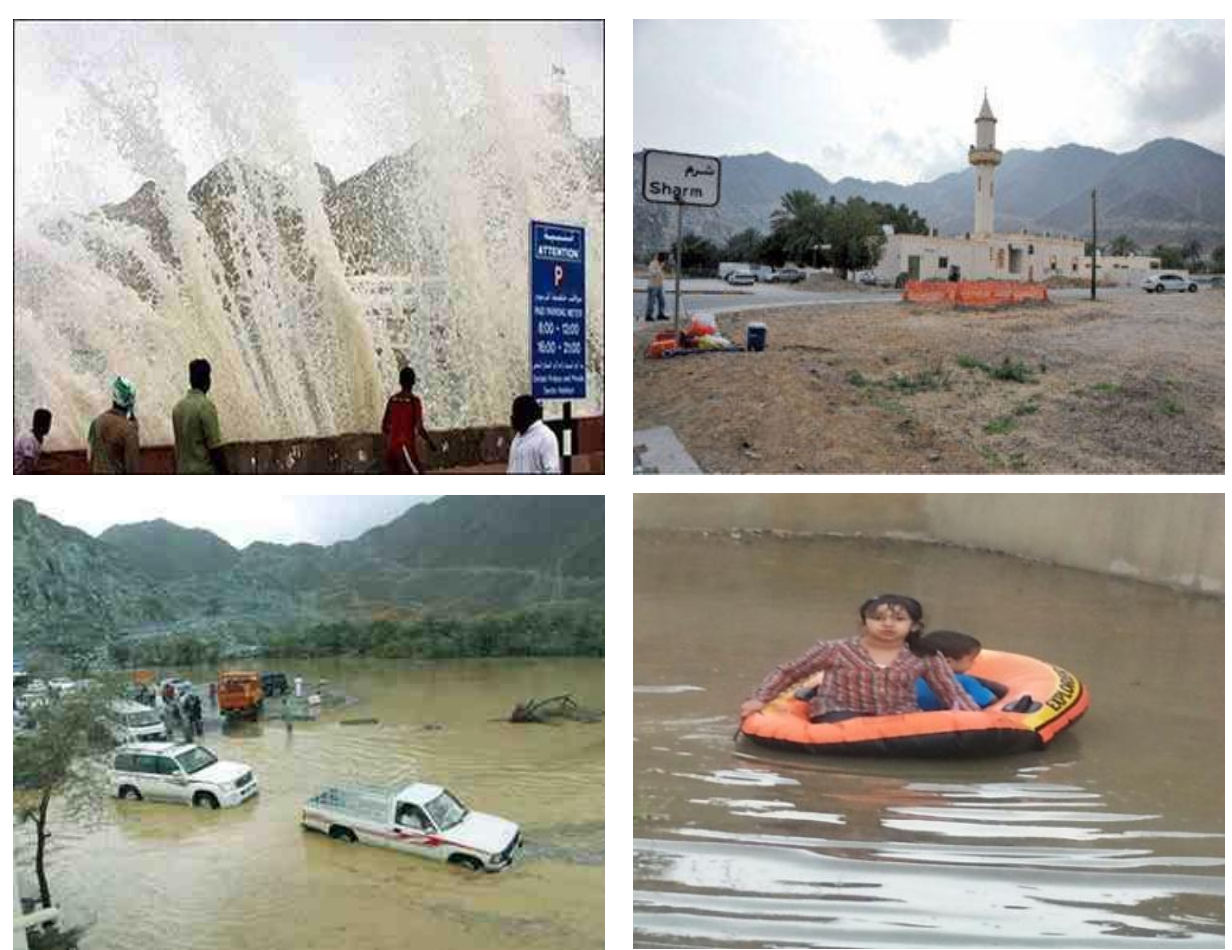

Fig. 3 The pictures (A, B) show the Phet storms, which hit the coast of Fujairah in 2010 and caused considerable material damage.

Table 1 Results of decision-makers interviews.

\begin{tabular}{|c|c|c|c|c|}
\hline No & Question & No $(\%)$ & $\begin{array}{l}\text { Don’t } \\
(\%)\end{array}$ & ${ }^{\text {know }}$ Notes \\
\hline 1 & $\begin{array}{l}\text { Does any Early warning system (a system to give an alert before and event starts } \\
\text { based on certain indicators) for Natural disaster (Local storm, Tropical Cyclone, } 40 \\
\text { Flood, Earthquakes and landslides) exist at the UAE? }\end{array}$ & 40 & 20 & \\
\hline 2 & $\begin{array}{l}\text { Do you participate in the activities related to decision-making process related to } 60 \\
\text { natural hazards? }\end{array}$ & 40 & 0.00 & \\
\hline 3 & $\begin{array}{l}\text { Have you got any coordination of regional data collection and monitoring (e.g., } 60 \\
\text { gauges, buoys) between your institutes and other stakeholders? }\end{array}$ & 40 & 0.00 & \\
\hline 4 & $\begin{array}{l}\text { Do you have any financial support from the government to improve early warning } 40 \\
\text { systems? }\end{array}$ & 60 & 0.00 & \\
\hline 5 & Do you release or receive the Warning Messages? & 60 & 0.00 & \\
\hline 6 & Do you have any process for feedback and learn from last natural hazards? & 20 & 60 & \\
\hline 7 & $\begin{array}{l}\text { Does your institution hold emergency exercises (for preparation and evacuation in } 80 \\
\text { case of an emergency) for the community? }\end{array}$ & 20 & 0.00 & \\
\hline 8 & Have the hazards, vulnerabilities and risks are monitored on an ongoing basis? & 40 & 0.00 & \\
\hline 9 & $\begin{array}{l}\text { In the present, can people in the community obtain information about natural risks } 20 \\
\text { and hazards (from your institutes)? }\end{array}$ & 80 & 0.00 & \\
\hline
\end{tabular}

- The participation in the decision making relating to planning for the natural disaster management and risks, in the Emirate of Fujairah is non-integrated; participation in the making of such decisions is only $60 \%$.

- The participation in exercises relating to the natural disaster management and risks, in the Emirate of Fujairah has amounted to only $80 \%$.

- The reviewing process for plans relating to the natural disaster management and risks, in the Emirate of Abu Dhabi and feedback from there, has amounted to only $20 \%$.

\section{Section 1: Knowledge of the Risks}

\section{Type/Name of the Organization: Fujairah Civil}

Defence: As for the current situation for the civil defence departments, there is no device or early warning for natural disasters, but laws and regulations stipulate that the country seeks to develop all of its 
institutions. As for the National Crises and Disasters Authority, they have plans for confronting crises and disasters. The tasks and duties of each body have been identified for confronting natural disasters such as hurricanes, earthquakes, floods, rain and landslides, as well as coordination with the authorities and other parties in the community.

Type/Name of the Organization: Fujairah Municipality: There are phones, televisions and radios similar to other countries.

\section{Section 2: Monitoring and Prediction}

Type/Name of the Organization: Civil Defence/The Emirate of Fujairah: There was a prior coordination between Civil Defence and the National Crises and Disasters Authority to set up scenarios and some specialized units to respond to some crises and disasters. Natural disasters such as floods, earthquakes and extreme rainfall have been allocated to the Ministry of Interior, in particular, the civil defence. Other disasters, such as epidemics are the responsibility of the Ministry of Health. There are continuous exercises, meetings and assessments based on previous disasters with the National Crises and Disasters Authority. In particular, disasters that have occurred during the past years, from rainfall and floods at the Free Zone, and the decisions that have been made after the disaster.

Type/Name of the Organization: Fujairah Municipality: in coordination with the authorities, especially with the National Crises and Disasters Authority and others authorities.

\section{Section 3: Publishing and Communications}

Type/Name of the Organization: Civil Defence/The Emirate of Fujairah: Warning messages are not sent, but sometimes when heavy rain is falling, various mass media are contacted and advice for the community is issued. The public are advised not to approach dangerous places. News from Fujairah Airport and the Central Operations is received, following the monitoring of developing events such as Hurricane Gonu and its tsunami.
Information such as the direction and speed of wind, its proximity to the coast, and its impact upon arrival is monitored.

Type/Name of the Organization: Fujairah Municipality: A warning is received via the mail. There is an emergency office. Rainfall warnings are received from Fujairah Police GHQ.

No warning messages are issued and the municipality has no jurisdiction for issuing warning messages. A real disaster has never occurred which required warning. The issuing of warning is also the jurisdiction of other authorities, such as civil defence.

\section{Section 4: Response Capacity}

Type/Name of the Organization: Civil Defence/The Emirate of Fujairah: In the Civil Defence, a portfolio has been created for the leaders and teams that may be involved responding to a disaster. The portfolio is continuously being developed and reviewed in terms of training, risks and the formation of specific teams, in particular from educational institutions. A team is formed with the school because the largest segment of the community is the school students. Advantages are taken of the administrative staff in schools, helping in the provision of shelters and student guidance in the event of a natural disaster.

Type/Name of the Organization: Fujairah Municipality: No serious incident has occurred requiring a response. However an incident has occurred on the wall of Kalba, and the result was the construction of the City's Corniche.

\section{A Case Study in Egypt}

Egypt is the second most populous country in Africa. Its population is over 64 million and growing at 1.66\% per year. Cairo, the capital, has become a mega-city, with a population of 15 million (the World Bank 2003). The potential impacts of extreme events such as storm surges on the coastal zone of the Arab region have also been investigated by the World Bank. It indicates that increasing surges will negatively impact Egypt the 
most. The coastal zones of Egypt are perceived as vulnerable to the impacts of climate change, not only because of the direct impact of sea level rise, but also the potential impacts of climate changes on their water resources, agricultural resources, tourism and human settlements. In particular, the low lying Nile Delta region, which constitutes the main agricultural land of Egypt and hosts over one-third of the population and nearly half of all its crops, industrial activities and commercial centers, is highly vulnerable to various impacts of climate change. The coastal zones of Egypt host a major part of the industrial activities including petroleum, chemicals and tourism distributed among a large number of highly populated economic centers such as the city of Alexandria. Natural disasters and climate change impacts would cost the city of Alexandria approximately $\$ 1.72$ billion during 2010 to 2030 period.
Alexandria is the second largest city and the second largest metropolitan area in Egypt after Greater Cairo by size and population. It extends about $75.00 \mathrm{~km}$ (20 mi) along the coast of the Mediterranean Seain the north central part of the country. Alexandria has the largest harbor in the country and roughly $40 \%$ of Egyptian industrial activities (Fig. 4).

\subsection{Description of the Disaster}

Egypt is among the countries most affected by climate changes, whose negative consequences are already apparent in the rate of depression of some land in Alexandria, which currently stands at five millimeters annually. Alexandria has frequent coastal floods each year, causing severe problems to communities and to the environment (Fig. 5).

Severe damage is caused to the coastal municipal infrastructure, roads and houses. No EWS alerts people

\subsection{Location}

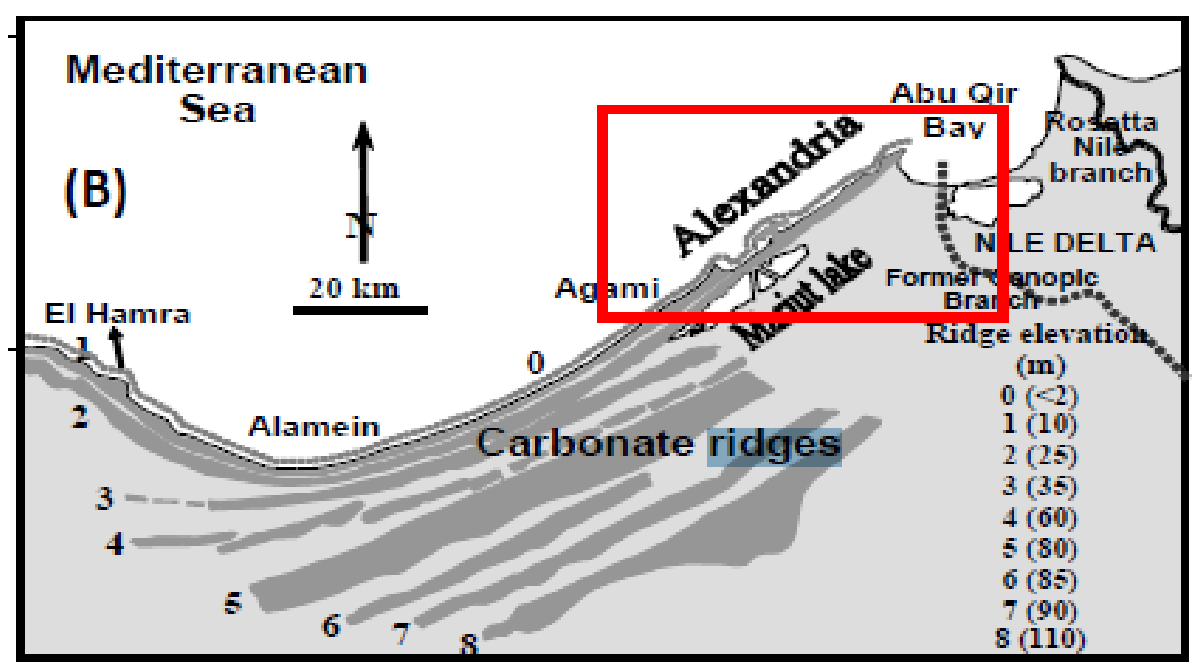

Fig. 4 General physiographic features of Alexandria (El Raey, 2009). 

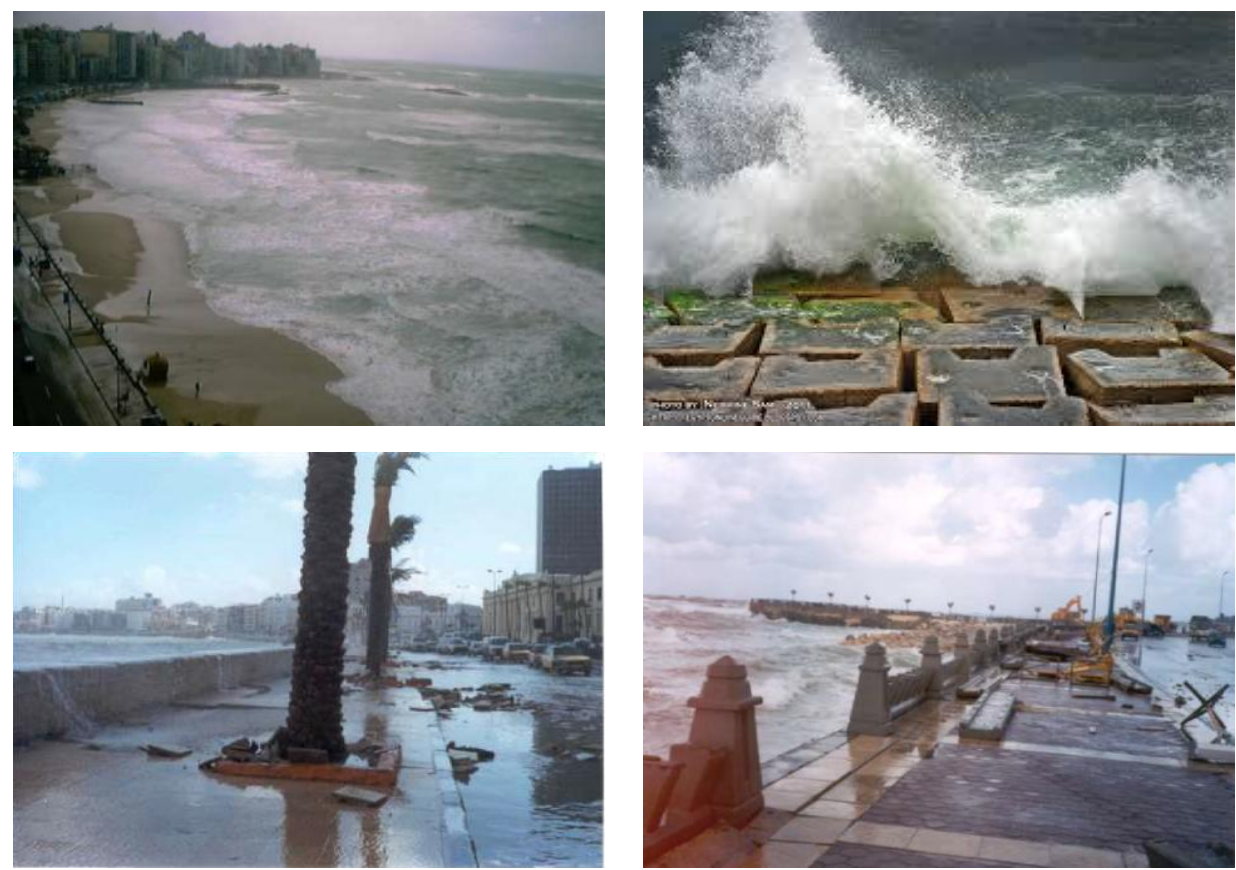

Fig. 5 The pictures show the storms, which hit the coast of Alexandria and caused considerable material damage (EI Raey, 2010).

in risk areas in advance. There is limited use of technology, such as EMS and telephones. There is poor institutional cooperation.

\subsection{Analyzing Field Survey Results in Sample Study in Alexandria}

Results of the questionnaire indicated: (1) A clear agreement of almost all stakeholders of the need is to protect the area; (2) A strong feeling among most stakeholders that cost is the main obstacle; (3) A weak tendency among stakeholders is to change jobs in response to the effects of climate change; (4) A wide variation of opinions concerning barriers, responses, and recommended actions, which may reflect the various interests of stakeholders and their flexibility to respond to coastal problems; (5) A low percentage of stakeholders are not interested in the subject. The ADM (Adaptation Decision Matrix) for coastal resources in Alexandria is shown in Table 2.

\begin{tabular}{|c|c|c|c|c|c|c|c|c|c|}
\hline \multirow[b]{2}{*}{ Measure } & \multirow[b]{2}{*}{ Scenario } & \multicolumn{4}{|c|}{ Weighted Objectives } & \multirow[b]{2}{*}{ Score } & \multirow[b]{2}{*}{$\begin{array}{l}\text { Total } \\
\text { score }\end{array}$} & \multirow[b]{2}{*}{$\begin{array}{l}\text { Cost of } \\
\text { measure } \\
(\text { million US \$) }\end{array}$} & \multirow[b]{2}{*}{$\begin{array}{l}\text { Cost-effectiveness } \\
\text { (cost/incre-mental } \\
\text { unit of benefit) }\end{array}$} \\
\hline & & $\begin{array}{l}\text { Property } \\
\text { Protection } \\
(3)\end{array}$ & $\begin{array}{l}\text { Flood } \\
\text { Avoidance } \\
(3)\end{array}$ & $\begin{array}{l}\text { Coastal } \\
\text { Development } \\
(3)\end{array}$ & $\begin{array}{l}\text { Wetland } \\
\text { Preservation } \\
(1)\end{array}$ & & & & \\
\hline \multirow{2}{*}{ Current policy } & Rise & 6 & 5 & 4 & 2 & 47 & \multirow{2}{*}{95} & \multirow{2}{*}{$\mathrm{Na}$} & \multirow{2}{*}{$\mathrm{Na}$} \\
\hline & No rise & 5 & 3 & 7 & 3 & 48 & & & \\
\hline $\begin{array}{l}\text { Beach } \\
\text { nourishment }\end{array}$ & $\begin{array}{l}\text { Rise } \\
\text { No rise }\end{array}$ & $\begin{array}{l}7 \\
9\end{array}$ & $\begin{array}{l}6 \\
7\end{array}$ & $\begin{array}{l}8 \\
9\end{array}$ & $\begin{array}{l}6 \\
6\end{array}$ & $\begin{array}{l}69 \\
81\end{array}$ & 150 & 54 & 0.98 \\
\hline Breakwaters & $\begin{array}{l}\text { Rise } \\
\text { No rise }\end{array}$ & $\begin{array}{l}8 \\
8\end{array}$ & $\begin{array}{l}8 \\
8\end{array}$ & $\begin{array}{l}5 \\
7\end{array}$ & $\begin{array}{l}7 \\
8\end{array}$ & $\begin{array}{l}70 \\
80\end{array}$ & 150 & 468 & 8.5 \\
\hline $\begin{array}{l}\text { Legal } \\
\text { Regulation }\end{array}$ & $\begin{array}{l}\text { Rise } \\
\text { No rise }\end{array}$ & $\begin{array}{l}2 \\
8\end{array}$ & $\begin{array}{l}2 \\
8\end{array}$ & $\begin{array}{l}3 \\
7\end{array}$ & $\begin{array}{l}4 \\
7\end{array}$ & $\begin{array}{l}25 \\
76\end{array}$ & 101 & 20 & 3.3 \\
\hline ICZM & $\begin{array}{l}\text { Rise } \\
\text { No rise }\end{array}$ & $\begin{array}{l}8 \\
9\end{array}$ & $\begin{array}{l}7 \\
8\end{array}$ & $\begin{array}{l}7 \\
9\end{array}$ & $\begin{array}{l}7 \\
7\end{array}$ & $\begin{array}{l}73 \\
85\end{array}$ & 158 & 550 & 8.7 \\
\hline $\begin{array}{l}\text { Land use } \\
\text { Change }\end{array}$ & $\begin{array}{l}\text { Rise } \\
\text { No rise }\end{array}$ & $\begin{array}{l}3 \\
8\end{array}$ & $\begin{array}{l}2 \\
7\end{array}$ & $\begin{array}{l}3 \\
6\end{array}$ & $\begin{array}{l}6 \\
7\end{array}$ & $\begin{array}{l}30 \\
70\end{array}$ & 100 & 900 & 180.0 \\
\hline
\end{tabular}




\section{Integrated Elements of Early Warning Systems}

(1) Strengthening the monitoring and early warning systems, in order to better prepare the city against extreme weather events.

(2) Preparation and self-protection against fast-impacting phenomena via information and education campaigns.

(3) Upgrading awareness and building national capacities.

(4) A data base of systematic observation of sea level parameters, such as sea level, storm surges, water and soil salinity, coastal temperatures and phytoplankton, erosional patterns and coastal socioeconomic parameters, must be established.

So as to prop up resilience building, the focus on EWS should not only be hazards but also on the notion of exposure. There is a need for EWS to be improved so that people are not only warned before the event of a hazard impacting a society, but also have a say in making sure that the livelihoods/lives at risk are secure from the gradual changes that are brought by climate change.

There is a need for information on hazard pattern changes to be merged with knowledge and forecasts about the development of vulnerabilities. The combination of the two will present the foundation of high quality EWS.

There is no sustainability in isolated or individual hazard, especially in the context of dealing with the challenges related to climate change. This calls for the need to give an explanation for rapid and gradual hazards simultaneously (for example, the potential significance of storm surges and sea level rise).

Top-down, technocratic, expert-driven and linear EWS separately are not effective at reducing damage and saving lives. A mixed institutional approach that includes both formal and informal phases is frequently indispensable. In such a scenario, the system does not control the people at risk but the people are an essential part of the system, thus create a people-centered approach. This entails to combine different types of knowledge in EWS, especially by connecting scientific and traditional knowledge.

The development process of EWS entails a multi-disciplinary approach. This approach must recognize all the stakeholders in the community and along the chain. It must also strive to build partnership and dialogues instead of being based on a top-down alert process.

The human assets and preparedness approaches connected with the EWS are especially imperative in low-technology places.

There is supposed to be a change towards working, relating and communicating "with" the community as opposed to "for" the community.

The shift of EWS technologies in dissimilar societal and cultural settings raises the question of robust and the abilities of the societies to uptake such complicated technologies devoid of dealing with the digital divide governance problem.

In addition, the new technologies and communication platforms like Facebook and Twitter and the internet generally have to be understood better. This is in terms of their roles in enlightening and warning people in situations of calamity.

The effectiveness and sustainability of EWS is driven by the systems of governance, which is economic, political and socio-technological.

The founding and development of EWS should be an essential objective of both rural and urban planning ads connected sectors.

So far, EWS has been very effective in identifying sudden-onset hazards at the same time creeping societal tipping points and environmental changes that are imperative dynamics in making decisions to migrate. In terms of displacement, EWS has not been adequately well-thought-out, or at least has not gotten much interest compared to hazard detection.

\section{References}

[1] Massoud, M. A., Scrimshawa, M. D., and Lestera, J. N. 2003. "Qualitative Assessment of the Effectiveness of the 
Mediterranean Action Plan: Wastewater Management in the Mediterranean Region." Ocean and Coastal Management 46: 875-99.

[2] Dhanhani, H. 2010. "Evaluation of the Response Cap ability of the United Arab Emirates to the Impact of Natural Hazards." Ph.D. thesis, University of Bedfor dshire. [Online] URI: http://hdI.handle.net/10547/24178 7.

[3] Golnaraghi, M. 2012. "Institutional Partnerships in M ulti-hazard Early Warning Systems.”A Compilation of Seven National Good Practices and Guiding Princip le. London: Springer, Ch. 2.

[4] Yin, R. 2003.Case Study Research: Design and Methods. London: Sage Publications.

[5] Saunders, M.N.K., Lewis, P., and Thornhill, A. 2009. Research Methods for Business.

[6] Yin, R. 2009. Case Study Research Design and Methods Thousand Oaks. London: Sage Publications.

[7] Creswell, J.W. 2007. Qualitative Inquiry \& Research Design. California: Sage.

[8] Fujairah Statistical yearbook Tenth issue 2007, Fujairah.

[9] Abdel, H., and Mohamed, A. R. 2009.Climate Chang $e$ in the Arab World, Threats and Response, In Trou bled Waters, Climate Change, Hydro politics and $\mathrm{Tr}$ ansboundary Resources, edited by David, M., and A mit, P. Washington DC: The Henry L. Stimson Cen ter.

[10] Al Ameri, F. 2010. Implementing an Effective Public Warning System in Abu Dhabi UAE. Coventry: Coventry University Press.

[11] Alzjeri, W. 2010 Cyclone Phet Hits the Eastern Coast of the UAE, emaratalyoum.com.

[12] Alrams, R. 2010. Alrams.net pictures. Accessed May 20, 2010. http://www.alrams.net/forum/showthread.php?t=3081.

[13] Dasgupta, S., Laplante, B., Meisner, C., and Yan, J. 2007. "The Impact of Sea Level Rise on Developing Countries: A Comparative Study." World Bank Policy Research Working Paper.

[14] El Raey, M. 2010. "Impact of Sea Level Rise on the Arab Region, University of Alexandria and Regional center for Disaster Risk Reduction Arab Academy of Science, Technology and Maritime Transport."

[15] El Raey, M., Agrawala, S., Moehner, A., Conway, D., Aalst, M., Hagenstad, M., andSmith, J. 1999. "D evelopment and Climate Change in Egypt: Focus on Coastal Resources and the Nile."

[16] Saunders, M. N. K., Lewis, P., and Thornhill, A. 2009. Research Methods for Business. Students (5th ed.). Harlow, United Kingdom: FT Prentice Hall.

[17] World Bank www.worldbank.org. 